TECHINCAT NOTE 4406

\title{
LOW TIRE FRICTION AND CORNERING FORCES ON A WET SURFACE
}

By Eziaslav N. Harrin

\author{
SUMMARY
}

An exploratory investigation was made by the National Advisory Committee for Aeronautics to study typical tire behavior on wet runways, to determine the mechanisms by which water on runways reduced tire forces, and to determine the extent of this tire-force reduction. A specially constructed tire treadmill served as a tire test vehicle which allowed easy control of such pertinent parameters as water depth on the treadway or belt which served as the runway, tire inflation pressure, belt velocity, braking load, yaw angle, and tire-tread pattern. A strain-gage balance mounted on the wheel chassis of the treadmill measured both the braking friction forces and cornering forces while tachometers recorded the wheel and belt velocities. Measurements of these parameters were made in testing a smooth-treaded and a diamond-treaded $3.00 \times 7$ tire.

Observations during the tests and evaluation of data have indicated that, under certain conditions of tire pressure, velocity, and water depth, the smooth-treaded tire stops rotating and begins to plane even without the application of brakes. For example, for a tire inflation pressure of $13 \frac{1}{2} \mathrm{lb} / \mathrm{sq}$ in. gage and a 0.09 -inch water depth, this planing condition occurred for the smooth tire at a velocity of 76 feet per second. The tire with the diamond tread behaved in a similar menner except that, instead of stopping completely, the wheel rotated at about 50 percent of the belt or treadmill speed. With both tires, the tire maximum and full-skid (locked wheel) braking friction coefficients decreased rapidly with increase in belt velocity, and for certain operating conditions of the smooth tire the full-skid braking-coefficient values fell below that of the rolling friction. In some of the cases for smooth tires the values of tire maximum braking friction coefficient dropped so low that the free-rolling friction became the maximum friction force. Under these conditions any slight and momentary braking forced the tire into a stable full-skid condition.

Cornering-force coefficients of both the smooth- and diamond-tread tires also decreased with belt velocity and reached nearly zero values at planing velocities. Braking had the effect of greatly decreasing the cornering-force coefficients even at relatively slow velocities. 


\section{INTIRODUCTION}

A number of accidents have been reported in which fighter alrcraft skidded off the runway in landing during, or immediately after, a heavy rain. In these accidents the braking and directional control were reported as extremely poor. It appeared that in these cases relatively thick water layers and high speeds were primary factors in the loss of traction of the tires on the runway surface. Several investigations have been made of tire friction coefficients on wet surfaces (refs. I to 6) but, in general, the test conditions were limited in speed, or degree of surface wetnesa, or both. The present investigation was therefore undertaken to study the effects of water depth, speed, and other factors on wet-surface tire characteristics. Tests were made with small smooth-treaded and dlamond-treaded tires (size $3.00 \times 7$ ) running on a treadmill or endless belt apparatus. The measurements covered speeds from 23 feet per second (approximately 14 knots) to 94 feet per second (approximately 55 knots), tire inflation pressures of 6 to 30 pounds per square inch, and water depths on the treadmill of $0.02,0.06$, and 0.09 inch. Measurements of braking. tire friction and cornering force were made at yaw angles of $0^{\circ}$ and $4^{\circ}$.

\section{APPARATUS AND THESTS}

The equipment was designed to be as small and simple as possible consistent with the requirement of reproducing the very poor braking conditions on wet runways reported by various agencies. Flementary theoretical considerations suggested that the poor braking condition results from a wedge of water forcing the tire away from contact with the runway and that the major parameter in this condition is the ratio of the square of speed to the tire inflation pressure. Accordingly, from tire characteristics and landing speeds involved in the poor braking incidents, it was estimated that with a commercially avallable $3.00 \times 7$ (2-ply rating, approximately 12-inch outside diameter) tire with an inflation pressure of 13 pounds per square inch, belt speeds and water speeds of 70 to 90 feet per second should be sufficient to produce the very low friction condition. This speed requirement and the small tire size made it possible to use commercially avallable belts and pulleys for the treadmill and normal fire-hydrant water pressure.

The treadmill (figs. I and 2) consisted of a commerclally available 10-inch wide, five-ply rating, power transmission belt that ran over 12-inch-diameter pulleys. Along the center line of the belt on the path of the tire, a 4-inch-wide coat of bonding agent impregnated with sand was la1d to approximate the texture of a concrete surface. Water was applied in a smooth sheet across the entire width of the sanded surface 
by means of a specially designed and built water nozzle in order to simulate standing water on a runway. The depth of thls sheet of water was not measured as such. It was assumed to be equivalent to the thickness of shim stock that could be slipped in between the upper water nozzle block (whose height was adjustable) and the sanded belt surface which served as the lower water nozzle block. The exit end of the nozzle block was located within $5 \frac{1}{2}$ inches of the tire so that the water depth was assumed to be the same at the tire as at the water nozzle exit. A gate valve located in the water feed pipe controlled the water pressure so that the water velocity at the nozzle exit matched the belt speed. The water velocity at this point was determined by means of a pitot tube located in the sheet of water at a position approximately $1 / 2$ inch downstream of the nozzle exit.

The braking and cornering forces were measured by a strain-gage balance which consisted of a vertically mounted beam (fig. 3) with bending-moment strain geges bonded onto its four faces. The braking and cornering forces were measured in the plane and normal to the plane of the wheel, respectively. The data from the strain gages were recorded on photographic film by means of standard NACA recording galvanometers. Tire braking was obtained by means of a small hydraulically operated. aircraft disk brake whereas cornering forces were obtained by rotating the wheel carriage and strain-gage balance about the vertical axis to provide a $4^{\circ}$ yaw angle. Wheel speeds and belt speeds were obtained from tachometer generators mounted on the axles of the test wheel and on the idler purley of the belt. Lag characteristics of the tachometer generator and recorder systems were such that accurate wheel velocities during deceleration were not obtainable so that data could not be presented as a function of slip ratio. Standard NACA tachometer recorders were used to record velocities.

In general, the data in this paper were obtained with the tires loaded to 100 pounds. The static tire footprint characteristics which were obtained from imprints of carbon-smeared tires upon a white cardboard surface for the two tire types under this load condition are presented in figure 4. At this load conaition the recomended inflation pressure was $13 \mathrm{lb} / \mathrm{sq}$ in. gage. Some exceptions to this load condition were a few tests with the diamond-treaded tire loaded with 50, 70, 90 , and 100 pounds of weights at three tire infletion pressures and with a belt velocity of about 82 feet per second. These exceptions are noted in this paper.

The smooth tire was tested at yaw angles of either $0^{\circ}$ or $4^{\circ}$, in water depths of 0.02 inch and 0.09 inch for each angle, and at three tire inflation pressures for each water depth (approximately 7, 13, and 28 pounds per square inch). 
All diamond-treaded-tire tests were made at one of two yaw angles $\left(0^{\circ}\right.$ or $\left.4^{\circ}\right)$. At the $0^{\circ}$ yaw angle, the tire was run in $0.02-, 0.06-$, and 0.09-1nch depths of water on the belt for each of the following tire inflation pressures: half normal ( 6 to $7 \frac{1}{4} \mathrm{lb} / \mathrm{sq}$ in.), normal ( $13 \frac{1}{2}$ to $16 \mathrm{lb} / \mathrm{sq} \mathrm{in}$. ), twice normal ( $28 \frac{1}{2}$ to $30 \mathrm{lb} / \mathrm{sq} \mathrm{in}$. ). At the $4^{\circ}$ yaw angle, the tire was run in 0.02 - and 0.09-inch depths of water. For the tests in which the tire operated at a $4^{\circ}$ yaw angle and in 0.02 inch of water, only the tire inflation pressure of $13 \frac{1}{2} \mathrm{lb} / \mathrm{sq}$ in. was used. As the result of damage incurred by the equipment during this test, the programed tests at tire inflation pressures of 7 and $28 \mathrm{lb} / \mathrm{sq}$ in. gage were not made. Tests with the tire running at a yaw angle of $4^{\circ}$ and in 0.09 inch of water were made at tire inflation pressures of $7,13 \frac{1}{2}$, and $28 \mathrm{lb} / \mathrm{sq}$ in. gage.

Belt velocities up to 93 feet per second (55 knots) were attalned. However, some tests were limited to lower speeds since the available water pressure was insufficient at times to have matching water and belt velocities at higher belt speeds.

For the most part, the instrument accuracies are believed to be of the order of 3 percent. Sample records are shown in figure 5 .

\section{DEFINITIONS OF COEFFICIENTS}

The coefficlents used in this paper are defined as follows:

Maximum braking friction coefficient: coefficient obtained by dividing the maximum braking force at a given velocity by the vertical force

Full-skld or locked-wheel braking friction coefficient: coefficlent obtained by dividing the friction force of a nonrotating wheel at a given belt velocity by the vertical force

Rolling friction coefficient: coefficient obtained by dividing the friction force of a freely rotating wheel with no braking by the vertical force

Free-roll wheel velocity: velocity of an unbraked wheel as obtained by multiplying the wheel rotational speed by the measured tire rolling radius

Cornering-force coefficlent: coefficient obtained by dividing the side force, measured perpendicular to the plane of the wheel, by the vertical force. 
All the coefficients are based on the vertical force and not on the static load (weight on wheel). The reason for this is that the pivot-point location of the wheel tow bar is such that the friction force produces a load-reducing moment on the tire. A summation of the static load and friction force moments about the pivot point determines the vertical force. This force is given by the formula

$$
F_{\mathrm{V}}=W-F_{\mathrm{f}}(\mathrm{h} / \mathrm{l})
$$

where

$\begin{array}{ll}\mathrm{F}_{\mathrm{V}} & \text { vertical force } \\ \mathrm{W} & \text { static load } \\ \mathrm{F}_{\mathrm{f}} & \text { friction force } \\ \mathrm{h} & \text { height of pivot point above tire-belt contact point } \\ \mathrm{l} & \text { distance of wheel from pivot point }\end{array}$

PRESENTATION OF RESULTS

Maximum braking friction coefficients, full-skid or locked-wheel braking friction coefficients, free-roll friction coefficient, and freeroll wheel velocity are presented in figures 6 to 14 as functions of belt velocity. Figures $6,8,10$, and 13 and figures $7,9,11$, and 14 are paired together to present data at generally the same conditions but at $0^{\circ}$ and $4^{\circ}$ yaw angles, respectively. Figure 12 presents data at $0^{\circ}$ yaw angle; there is no comparable figure at $4^{\circ}$ yaw angle. The alternate figures have two additional parameters - cornering-force coefficients at free roll and at maximum braking - also plotted as functions of belt velocity. Each of the aforementioned figures presents information obtained from a tire operated in a particular water depth and in most cases at three tire inflation pressures - approximately 7, 14, and $28 \mathrm{Ib} / \mathrm{sq}$ in. gage. However, because of equipment damage, the data taken for the tests shown in figure 11 are for the tire inflation pressure of $13 \frac{1}{2} 1 \mathrm{~b} / \mathrm{sq}$ in. gage only. Data taken at the two water depths of 0.02 and 0.09 inch used in tests of smooth tires are shown in figures 6 and 7 and figures 8 and 9, respectively. Diamond-treaded tire data taken at three water depths' $(0.02,0.06$, and 0.09 inch) are shown in figures 10 and 11, figure 12, and figures 13 and 14, respectively.

Figures 15 and 16 present the variation, which was obtained at a $4^{\circ}$ yaw angle and at three different speeds (approximately 27, 49, $71 \mathrm{ft} / \mathrm{sec}$, , of the cornering-force coefficient with braking friction 
force coefficient. Figure 15 presents these results for the smooth tire operated in 0.02- and 0.09-inch water depths and at three tire inflation pressures, whereas figure 16 presents data obtained at the same conditions as figure 15 but with a diamond-treaded tire substituted for the smooth tire. However, for reasons explained previously, only the data for a tire inflation pressure of $13 \frac{1}{2} \mathrm{lb} / \mathrm{sq}$ in. are available for the 0.02-inch water depth.

Varying the weight of the static load affects the friction coefficient of the diamond-treaded tire in the manner shown in figure 17 .

\section{DISCUSSION}

\section{Smooth-Tire Friction Coefficients}

An examination of the results presented in figures 6 to 9 for the smooth tire operated in either thin or thick films of water shows that, as the belt velocity increased, the values of maximum braking coefficients decreased until at certain high speeds the values either approached or equaled coefficlents of a freely rolling tire $(0.05$ to 0.09$)$. At these "certain high speeds" of the freely rolling tire, the spinning stopped without any brake application. From this it is apparent that water pressure at these conditions caused a complete separation of the tire from the belt and created torques which stopped tire spinning. This condition may be referred to as "tire-planing" and appears to be a stable condition.

Figures 6 to 9 also show the rapid decrease in values of full-skid (locked-wheel) braking friction coefficlents with increasing belt velocities. Values of these friction coefficients as low as 0.03 to 0.05 are reached at tire-planing velocities; furthermore, not only are these values low for a tire in full skld but they are also so low that they drop below those for the tire in free roll. It was found that under these friction-coefficient conditions and at belt speeds below that of tire planing, the smooth tire would elther not accelerate from a stopped condition, or would accelerate very slowly. The importance of this phenomena lies in the fact that a nonspinning tire, such as that on a landing aircraft, may not take advantage of higher braking friction coefflcients that exist at below tire planing speeds.

The values of the free-roll friction coefficient, on the other hand, increase with increasing velocity until apparently a maximum value is reathed at planing speed. Free-roll friction coefficient also increases with increasing water depth, but neither the tire inflation pressure nor the yaw angle seem to have much effect on the free-roll friction coefficient. 
It can be noted by inspecting figures 6 to 9 that the speed at which a smooth tire will plane is some function of tire pressure and water depth. Deeper water and lower tire pressures tend to lower the planing speed of the smooth tire; conversely, shallower water and higher tire pressures tend to increase the speed at which the smooth tire will plane. Some elementary considerations, which take into account the inertia of the water but neglect its viscosity, suggest that the parameter $p_{b}\left(\frac{l}{w}\right)^{2}$ (where $p_{b}$ is the tire-footprint bearing pressure, $\tau$ is the footprint length, and $w$ is the footprint width) determines the planing condition. However, the data are insufflcient to substantiate this formula.

\section{Friction Coefficients of the Diamond-Treaded Tire}

The results for the diamond-treaded tire (figs. 10 to 14) also show a decrease of maximum braking friction coefficients with increasing belt velocity. At the end of this large decrease in maximum braking friction coefficients is the diamond-treaded tire planing condition which is apparent by the low friction coefficients and a drop in freewheel velocity from belt velocity. In this case, as opposed to that of the smooth tire, some small braking effectiveness exists, the maximum braking coefficient being from 0.13 to 0.21 .

The values of the full-skid braking friction coefficients also show a decrease with increasing belt velocity. Moreover, these decreases are large even in cases where the decreases in the maximum braking force friction coefficients are relatively small, such as in the case of shallow water depths ( 0.02 inch) and zero yaw angle. As a result of these decreases, the full-skid braking coefficients are much smaller than the maximum braking coefficients at planing speeds. Thus at these speeds the full-skid braking-force friction coeffictents reach values which range as low as from 0.13 to 0.10 whereas free-roll wheel velocities decline to values nearly 66 percent below belt velocity. Furthermore, these values of wheel velocities are not necessarily the minimum since an examination of the free-wheel-roll velocity curve inaicates that further decreases may be expected at higher belt speeds.

The values of the free-roll friction coefficient of the diamondtreaded tire, in general, behave similarly to that of the smooth-treaded tire with the exception that the increase of the free-roll friction coefficient of the diamond-treaded tire is more rapid with increasing water depth.

From figures 12, 13, and 14, it can be seen that the behavior of planing speeds of the diamond-treaded tires depend on the same parameters 
as do the smooth tire, or higher tire pressures and shallower water depths produce higher planing speeds. However, the planing speeds for the diamond-treaded tire are somewhat greater than those for the smooth tire. Also, at the higher speeds the diamond-treaded-tire friction coefficlents at maximum braking and full skld are considerably greater than those for the smooth tire.

\section{Effect of $4^{\circ}$ Yaw Angle on Friction Coefficients of Both Tires}

The effect on the maximum braking friction coefflcient and fullskjd braking friction coefficient of setting both the smooth- and diamond-treaded tires at a $4^{\circ}$ yaw angle can be seen by comparing figure 6 with figure 7 , figure 8 with figure 9, figure 10 with figure 11 , and figure 13 with figure 14. The comparison shows a loss in values of the maximum braking force friction coefficient and full-skid braking friction force coefficient for both tread patterns.

\section{Cornering-Force Coefficient Characteristics}

\section{of Both Tires}

The effect of velocity on the cornering-force coefficients at maximum braking and free roll can be seen in figures $7,9,11$, and 14. As the velocity increases the values of the cornering-force coefficient decresse until at the tire-planing condition they become practically zero and thus render the tire useless for steering purposes. These flgures also show the serlous loss in cornering-force coefficient caused by brake application. The smooth tire can lose as much as 80 percent of its cornering-force coefficient at maximum braking even at the low speed of approximately 30 feet per second and a thin water film of 0.02 inch. This loss of cornering-force coefficient with increasing braking is shown more clearly in figures 15 and 16 for both types of tires and thin and thick films of water. A study of figures 15 and 16 shows that in the few cases at the higher belt velocities where the braking coefficient is in the usable range of values, the cornering-force coefficients are so low that the lack of steering abillties makes the tire's use questionable.

\section{Effect of Welght on Friction Coefficients of the Diamond-Treaded Tire}

The effect of reducing the vertical load on a diamond-treaded tire operating in 0.09 inch of water and at about 82 feet per second can be 
seen in figure 17. The flgure shows that at near planing speed the friction coefficients at maximum braking and full skid increase somewhat with a welght decrease. These increases in friction force coefficient range from 0.04 to 0.10 with a vertical-force reduction as high as 52 percent of the normal weight.

\section{Application of the Results to Full-Scale Tires}

It should be recognized that the foregoing results were obtained on a small low-pressure tire; however, it is believed that any tire will behave similarly under certain conditions. In fact, evidence of the tire planing phenomena has appeared in landings of aircraft varying from modern fighter to small executive types covering a range from highspeed, high-pressure to low-speed, low-pressure tires. Determination of the planing speeds - at least as a first approximation - of these tires might well be done by means of the parameter $\mathrm{p}_{\mathrm{b}}\left(\frac{2}{\mathrm{w}}\right)^{2}$ introduced earlier in the discussion. If the parameter is equated with the dynamic water pressure at planing speed multiplied by an experimental constant, an approximate value of planing speed in fairly deep water may be obtained. (The tentative value of the experimental constant was found from a few experimental points for the smooth tire in deep water, 0.09 inch, to be about 2.0.) Factors such as water depth, angle of yaw, and type of tire tread modify this parameter somewhat and should be considered for a more accurate determination of the planing speeds.

\section{CONCIUDING REMARKS}

An investigation was made to examine the effects of water on the runway upon the braking and cornering forces of tires. The results indicate that the maximum and the full-skid braking friction coefficients decrease rapidly with increasing velocity until all braking effectiveness is lost and a tire planing condition is reached. For the diamond-treaded tire these tire planing speeds are somewhet higher than those for the smooth tire as are the friction coefficients. Generally, the results indicate that these planing speeds decrease with increasing water depths and increase with increasing tire pressures. Roughly, at deeper water depths the tire-planing dynamic water pressure is a function of the tire-ground bearing pressure, possibly multiplied by some other functions, one of which may be the square of the length-width ratio of the tire footprint. As an example of a typical value of tire planing speed, the smooth tire at normal Inflation pressure $\left(13 \frac{1}{2} \mathrm{lb} / \mathrm{sq}\right.$ in.) and deep water (0.09 inch) 
begins to plane at 76 feet per second while the diamond-treaded tire begins to plane at about 79 feet per second.

Cornering forces developed at a $4^{\circ}$ yaw angle also decrease with Increasing velocity until they vanish at planing speeds. Serious losses In cornering-force coefficients (as great as 80 percent of the free-roll conditions) were also incurred at low speeds as the result of braking on wet surfaces.

Langley Aeronautical Laboratory, National Advisory Committee for Aeronautics, Langley Field, Va., August 27, 1958.

\section{REF'RERENTCES}

1. Förster, B.: Tests To Determine the Adhesive Power of Passenger-Car Tires. NACA TM 1416, 1956.

2. Gough, V. E., and Roberts, G. B.: Dunlop Cornering Force Machine. W. Heffer \& Sons Ltd. (Cambridge), 1957. (Reprinted from "Transactions of the Institution of the Rubber Industry," vol. 33, no. 5.)

3. Saal, R. N. J.: Laboratory Investigations Into the Slipperiness of Roads. Chemistry and Industry, vol. 55, no. 1, Jan. 1936, pp. 3-7.

4. Hall, Albert W., Sawyer, Richard H., and McKay, James M.: Study of Ground-Reaction Forces Measured During Landing Impacts of a Large Alrplane. NACA TN 4247, 1958. (Supersedes NACA RM L55E12c.)

5. Giles, C. G., and Lander, F. T. W.: The Skld-Reslsting Properties of Wet Surfaces at High Speeds: Exploratory Measurements With a Small Braking Force Tratler. Jour. R.A.S., vol. 60, no. 542, Feb. 1956, pp. 83-94.

6. Grime, G., and Giles, C. G.: The Skid-Resisting Properties of Roads and Tyres. Institution of Mechanical Engineers, Automobile Division Proceedings, 1954-1955, pp. 19-30. 


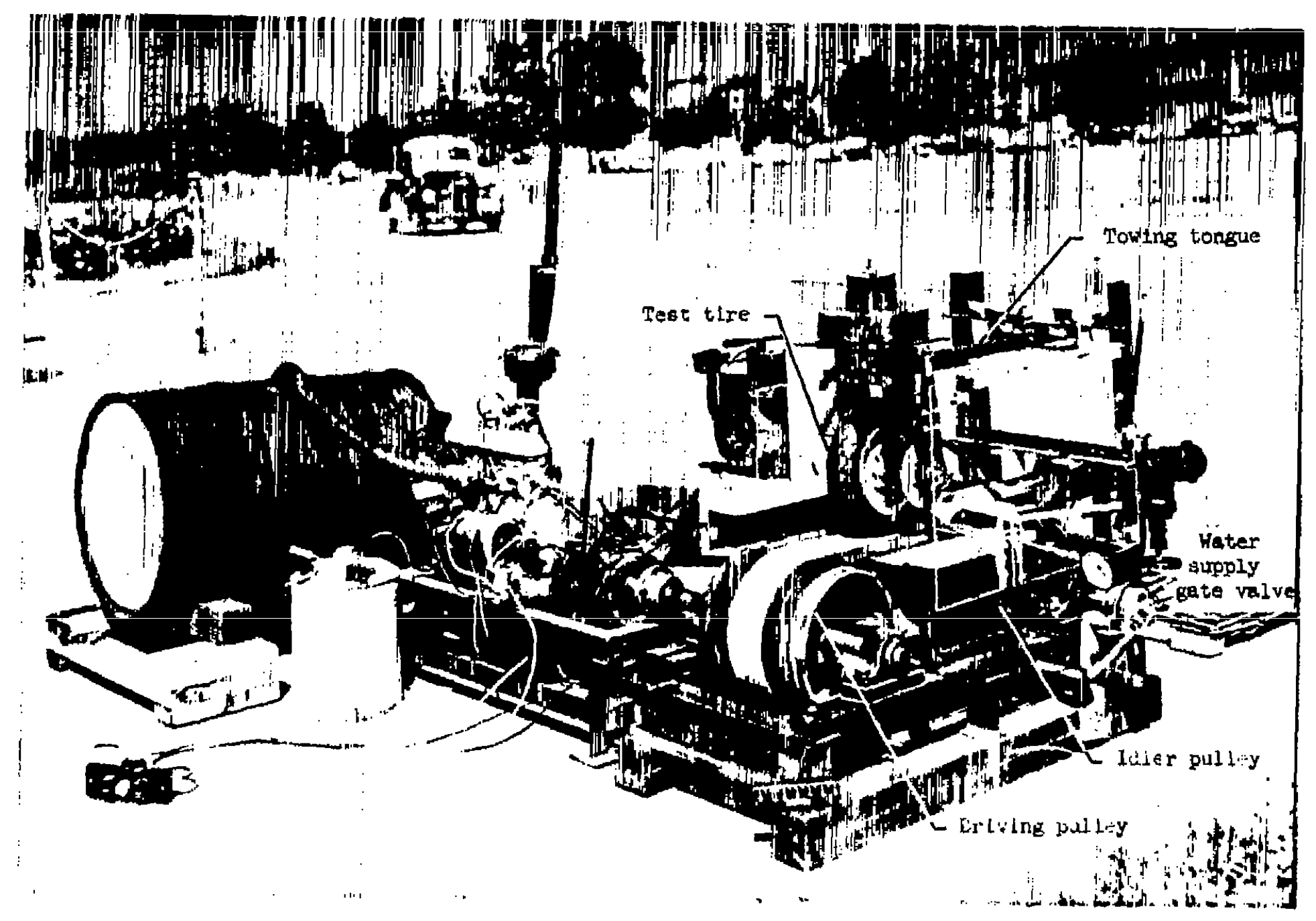

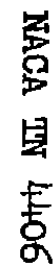

Figure 1.- General view of tire treadmill. L-57-2091.1 


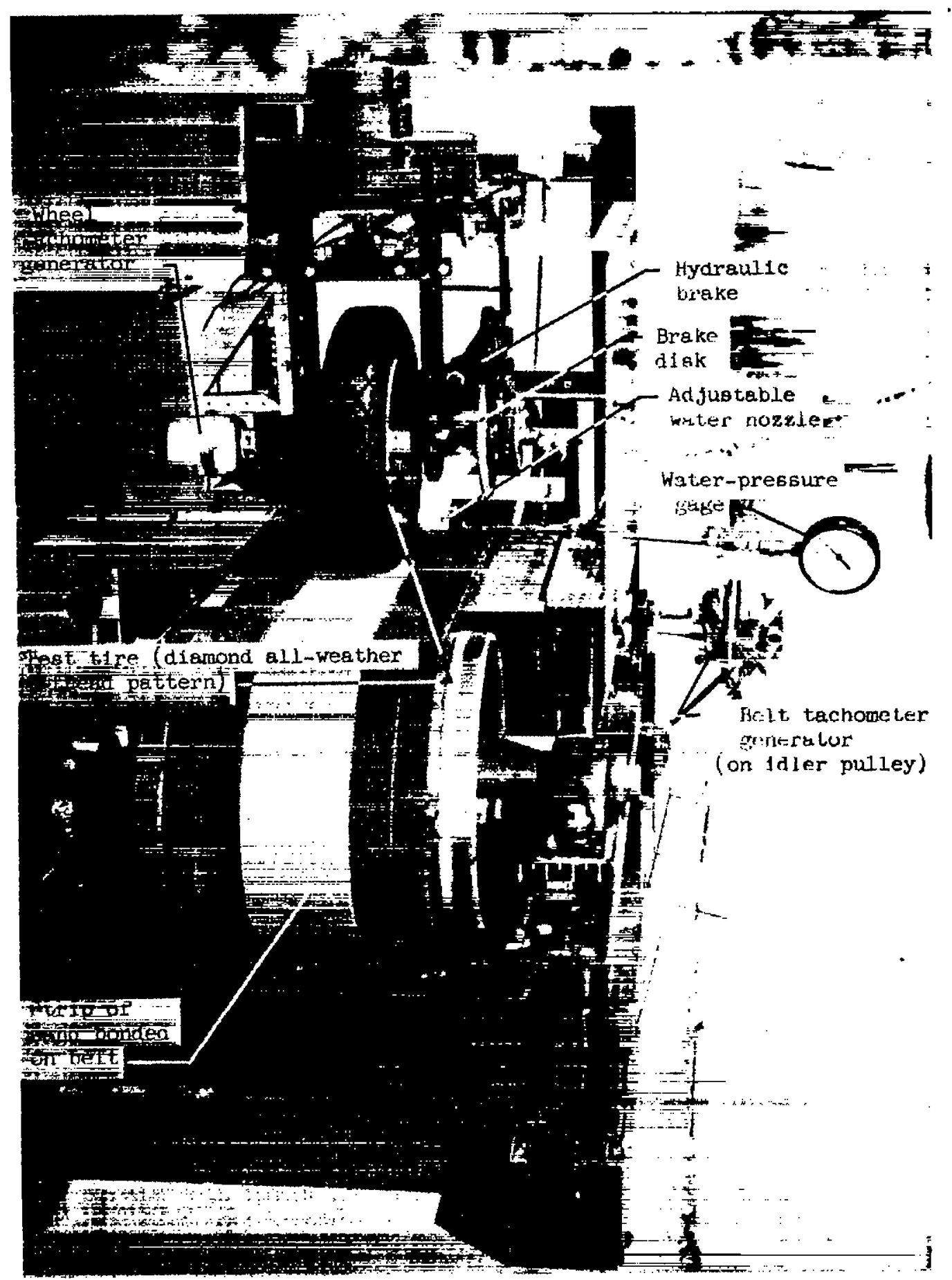

Figure 2.- Closeup view of tire treadmill. I-57-2093.I 


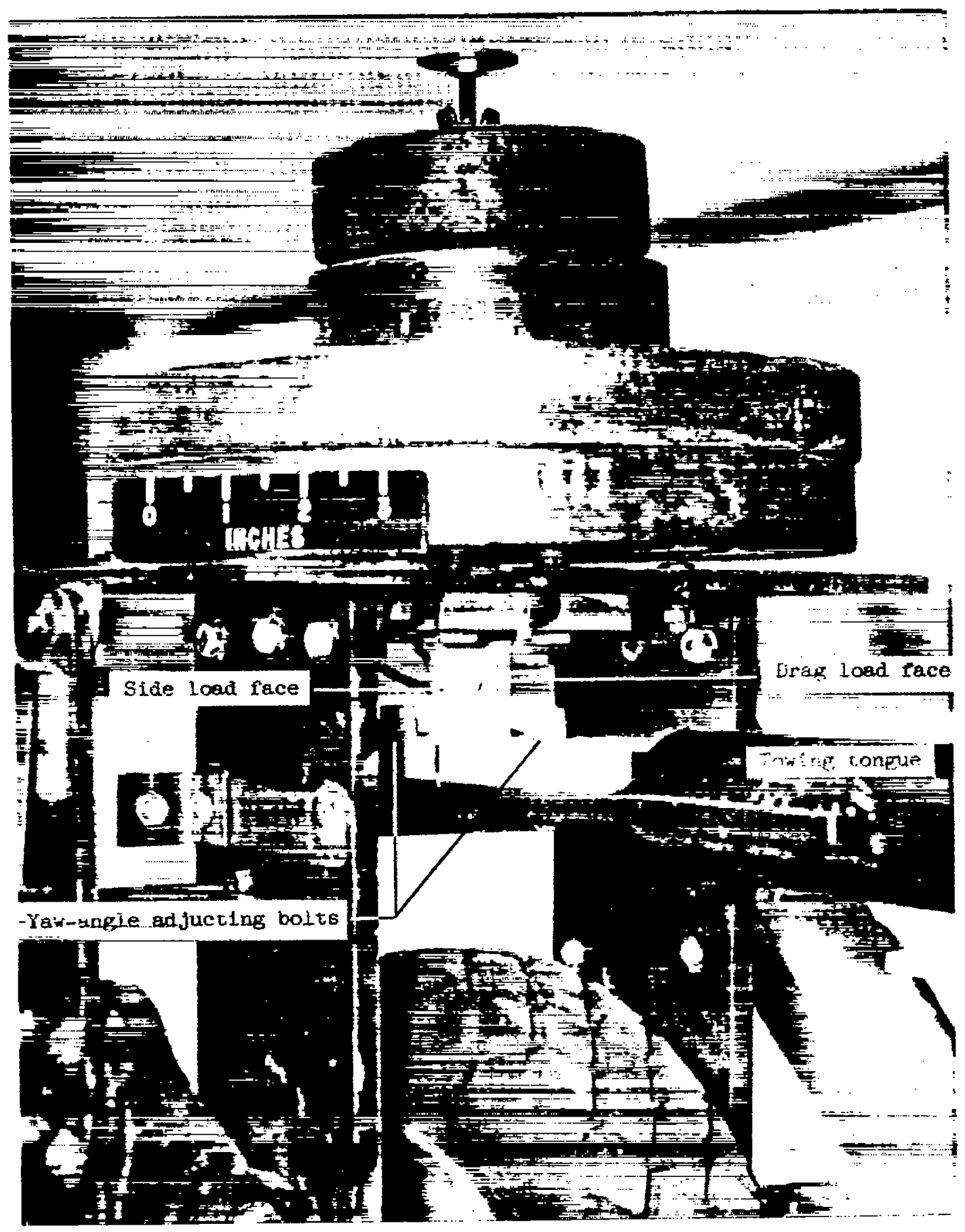

Figure 3.- Closeup view of strain-gage balance. I-57-2094.I 


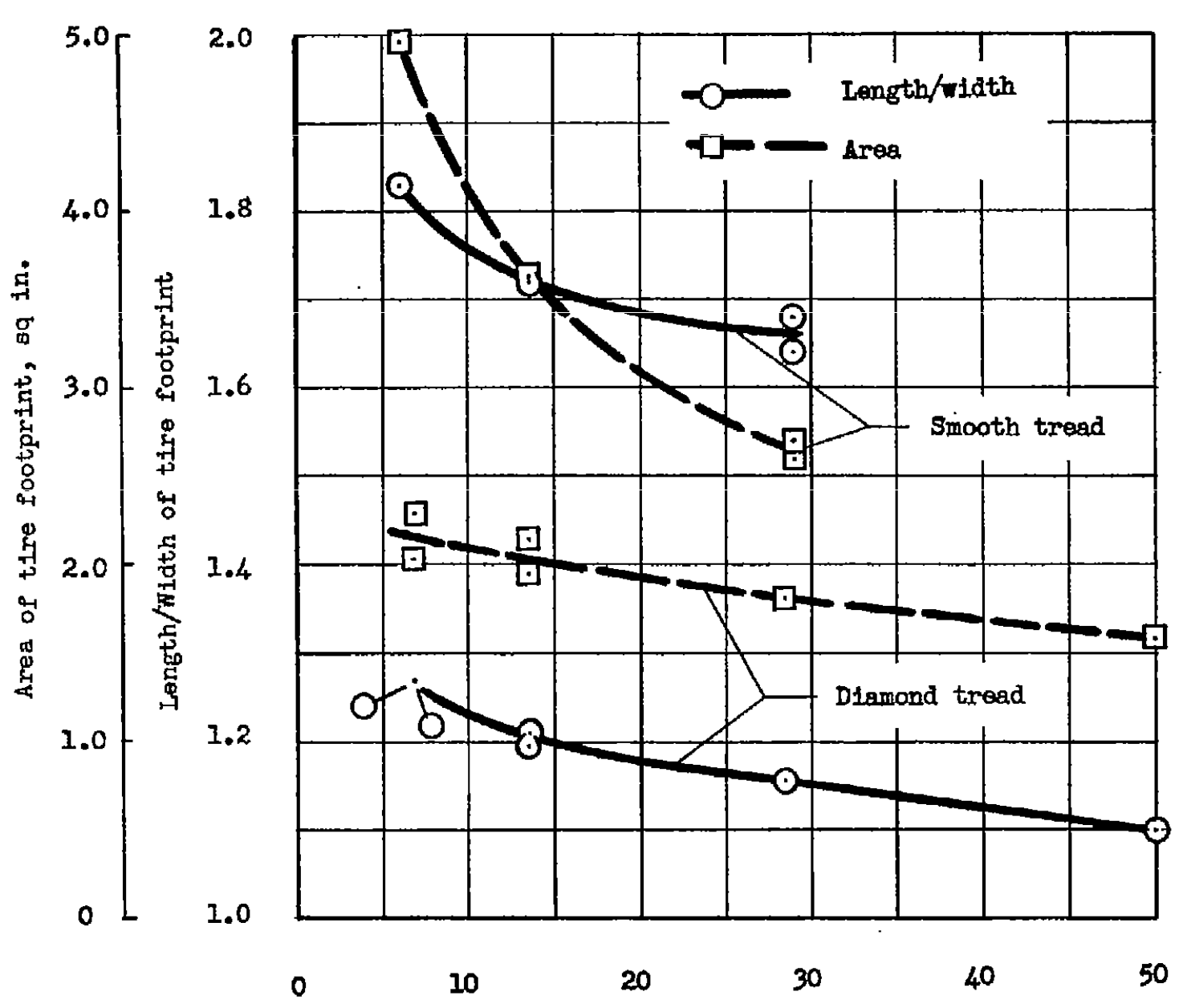

Gage tire pressure, Ib/sq in.

Figures 4.- Static tire footprint characteristics for the two tire types used in tests. Vertical static losd, 100 pounds. 


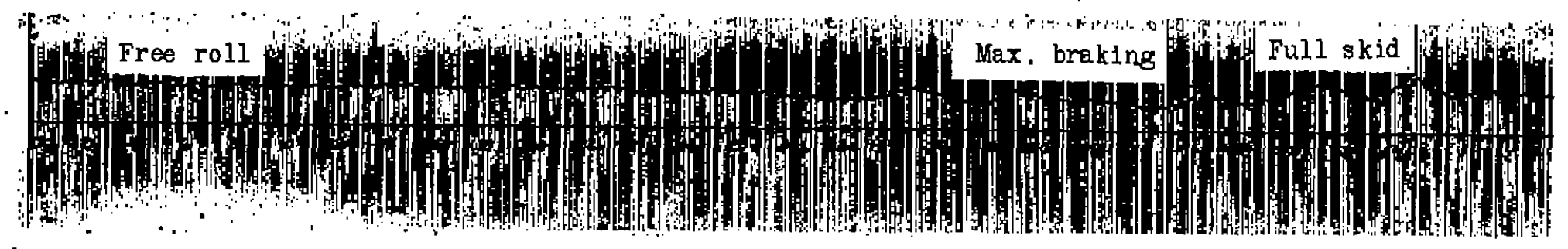

号
是
志

(a) Belt tachometer record.

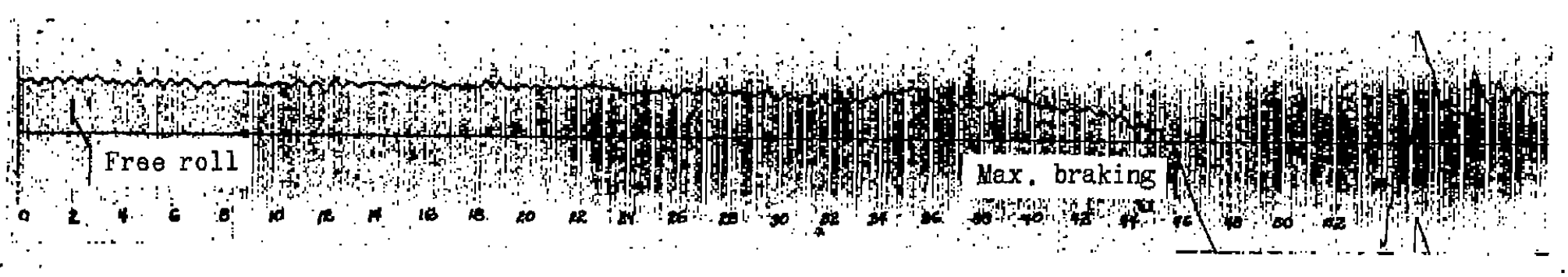

(b) Wheel tachometer record.

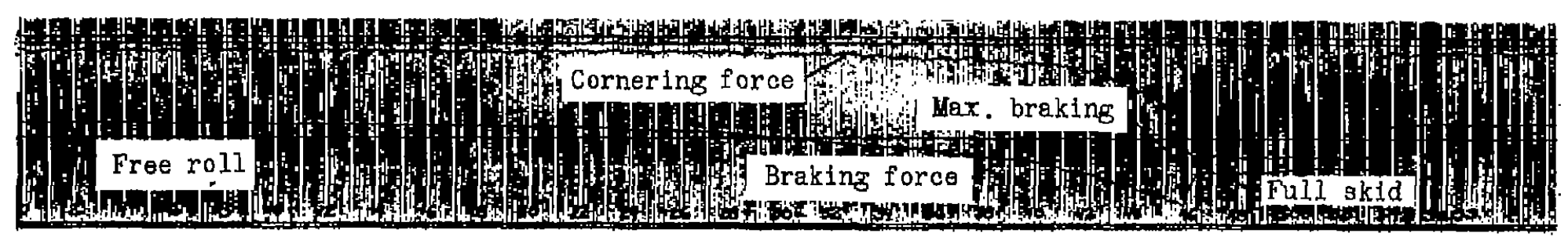

(c) Braking-force and cornering-farce galvanometer record.

Figure 5.- Sample record for diamond-treaded tire operating at a water depth of 0.09 Inch. Freeroll wheel velocity, $32.5 \mathrm{ft} / \mathrm{sec}$; belt velocity $\approx 31.0$ to $32.9 \mathrm{ft} / \mathrm{sec}$; free-roll frictlon coefficient, 0.01; maximum braking friction coefficlent, 0.51; full-skid friction coefficient, 0.28 ; free-roll comering-force coefficlent, 0.41 ; maximum braking cornering-force coefficlent, 0.09 ; and full-skid cornering-force coefficient, 0 . 


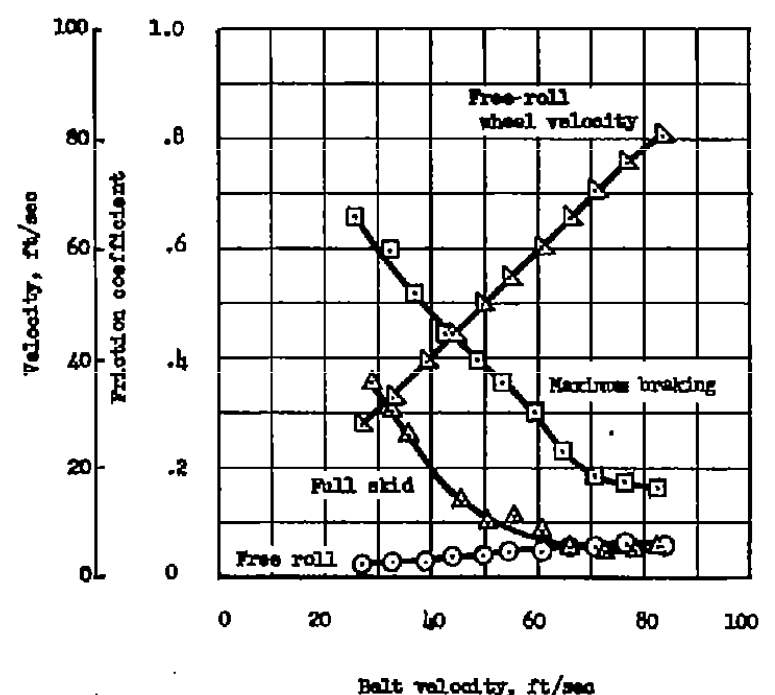

(a) Tire inflation pressure, $7 \frac{1}{2} \mathrm{Ib} / \mathrm{sq}$ in. gage.

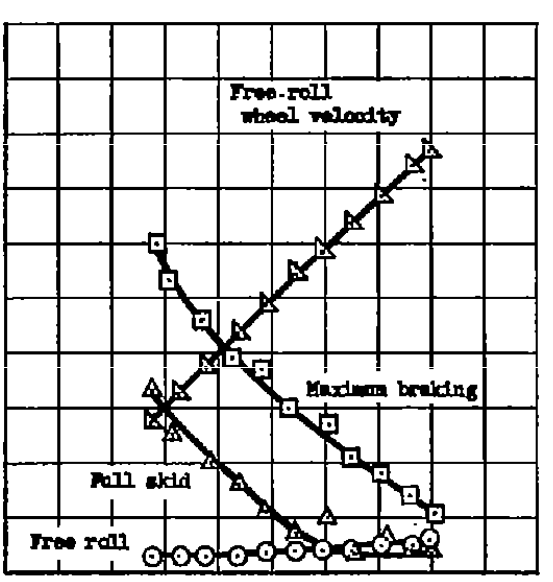

20

Belt valoodto, $\mathrm{rt} / \mathrm{sec}$

(b) Tire inflation pressure, $I 3 \frac{1}{2} \mathrm{lb} / \mathrm{sq}$ in. gage.

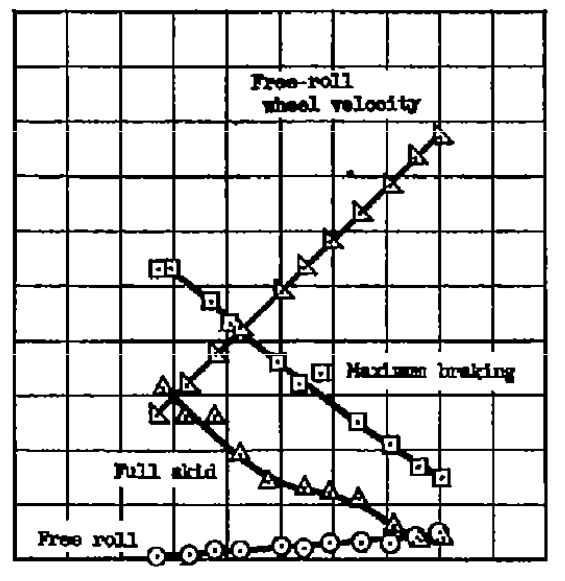

20

Bolt veloodts, itt/mos

(c) Tire inflation pressure, $28 \frac{1}{2} \mathrm{lo} / \mathrm{sq}$ in. gage.

Figure 6.- Variation of tire friction coefficient and wheel velocity with belt velocity.

0.02 -inch water depth; smooth-treaded tire; $0^{\circ}$ yaw angle; vertical static load, 100 pounds. 

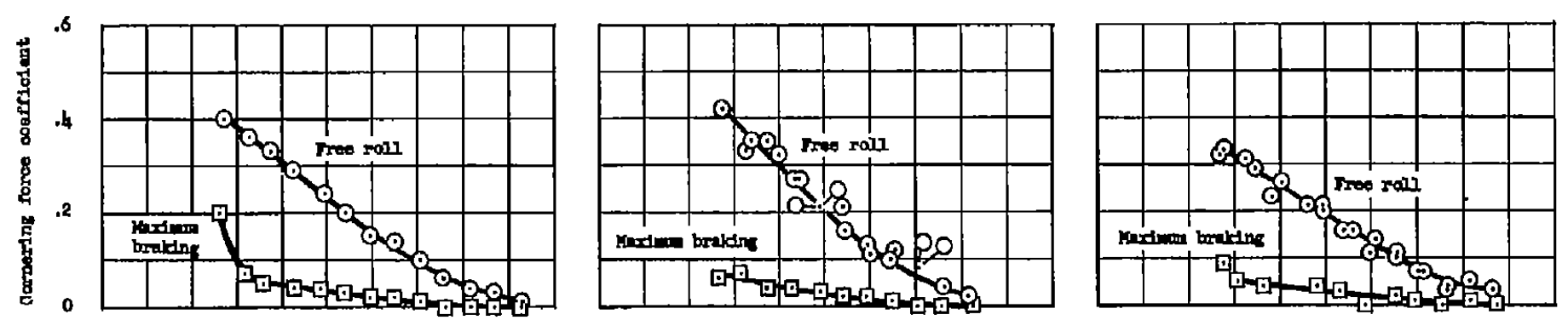

盗
是
志
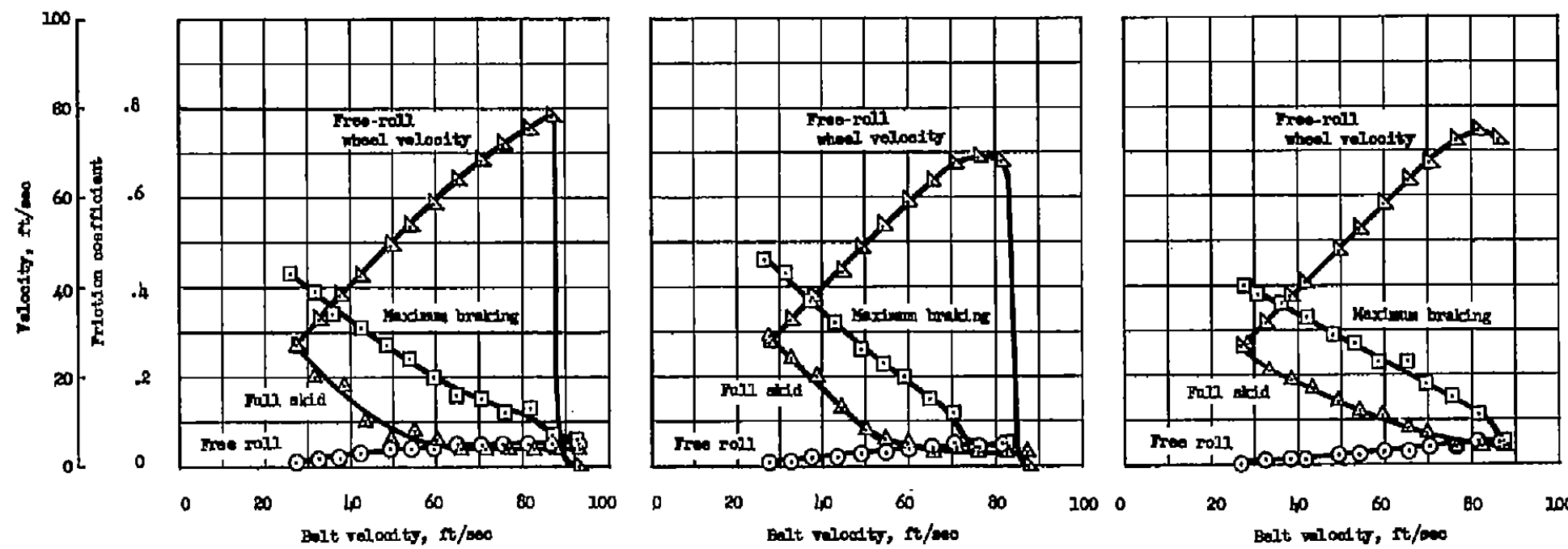

(a) T1re Inflation pressure, $7 \frac{1}{2} \mathrm{lb} / \mathrm{sq}$ in. gage.

(b) Tire inflation pressure, $13 \mathrm{lb} / \mathrm{sq}$ in. gage.
20 Belt viloolto, It/one

(c) Tire inflation pressure, $27 \frac{1}{2} \mathrm{lb} / \mathrm{sq}$ in. gage.

Figure 7.- Varlation of tire friction coefficlent, cornering-force coefficient, and wheel velocity with belt velocity. 0.02 -Inch water depth; smooth-treaded tire; $4^{\circ}$ yaw angle; vertical statilc load, 100 pounds. 


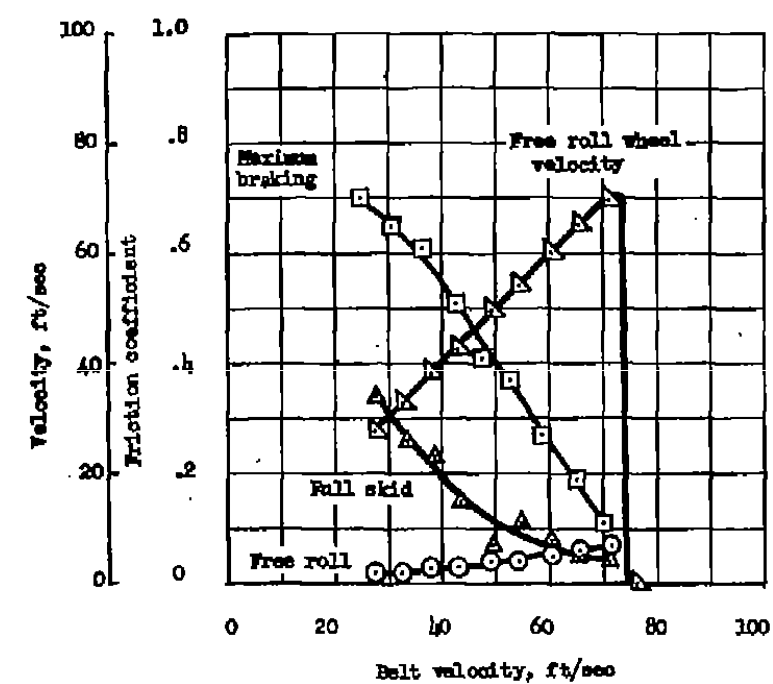

(a) Tire inflation pressure, $7 \mathrm{lb} / \mathrm{sq}$ in. gage.

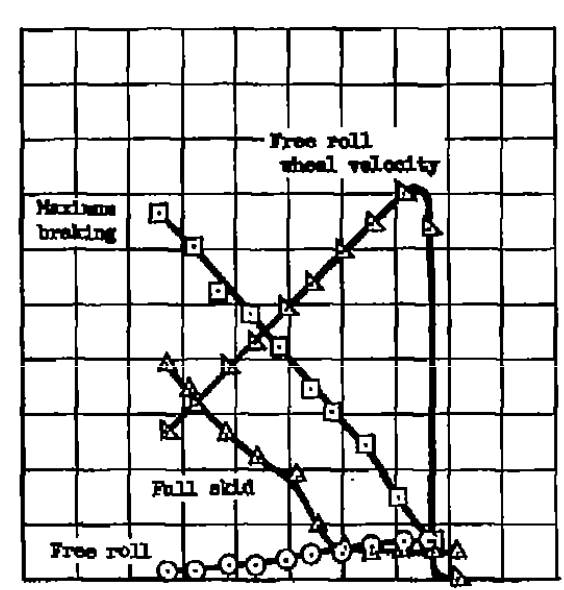

20
Bolt velouts, $5 t /$ apo

(b) Tire inflation pressure, $13 \frac{1}{2} 1 b / s q$ in. gage.

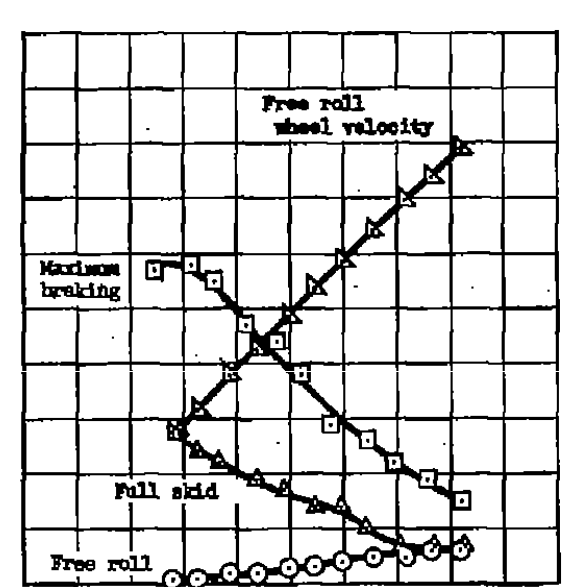

20 Belt woloolty, $f t / m$

(c) Tire inflation pressure, $28 \mathrm{Ib} / \mathrm{sq}$ in. gage.

FIgure 8.- Varlation of tire friction coefficient and wheel velocity with belt velocity.

0.09 -Inch water depth; smooth-treaded tire; $0^{\circ}$ yaw angle; vertical static load, 100 pounds. 

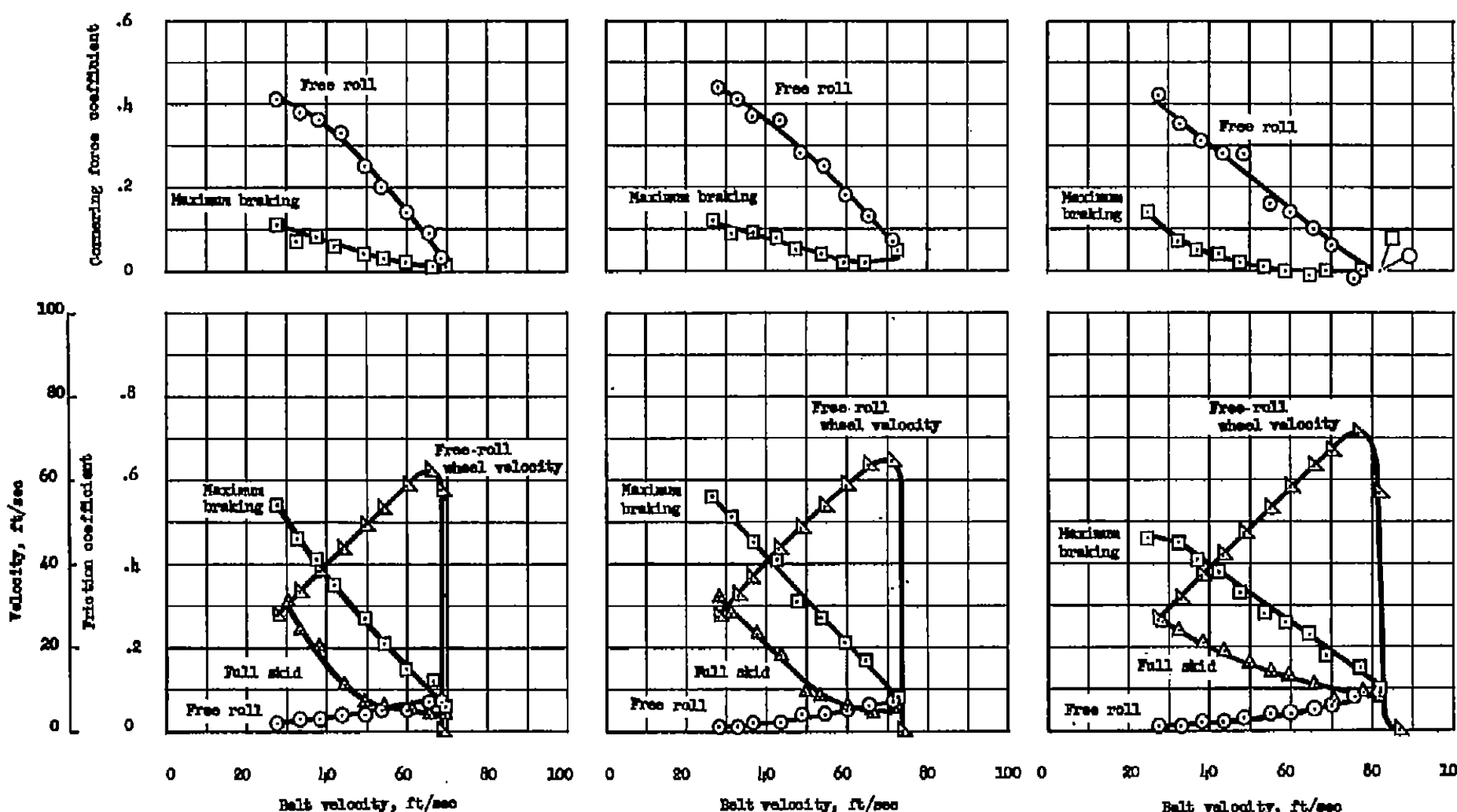

$80 \int_{B 01 t \text { raloos ty, } \pi / 1000} 60 \quad 00 \quad 1000$

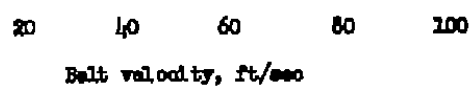

(a) Tire inflation pressure, $7 \frac{7}{2} \mathrm{lb} / \mathrm{sq}$ in. gage.

(b) T1re inflation pressure, $13 \frac{1}{2} \mathrm{lb} / \mathrm{sq}$ in. gage. (c) Tire inflation pressure, $28 \mathrm{lb} / \mathrm{sq}$ in. gage.

Figure 9.- Variation of tire friction coefficlent, cornering-force coefficlent, and wheel velocity with belt velocity. 0.09 -Inch water depth; smooth-treaded tire; $4^{\circ}$ yaw angle; vertical static load, 100 pounds. 


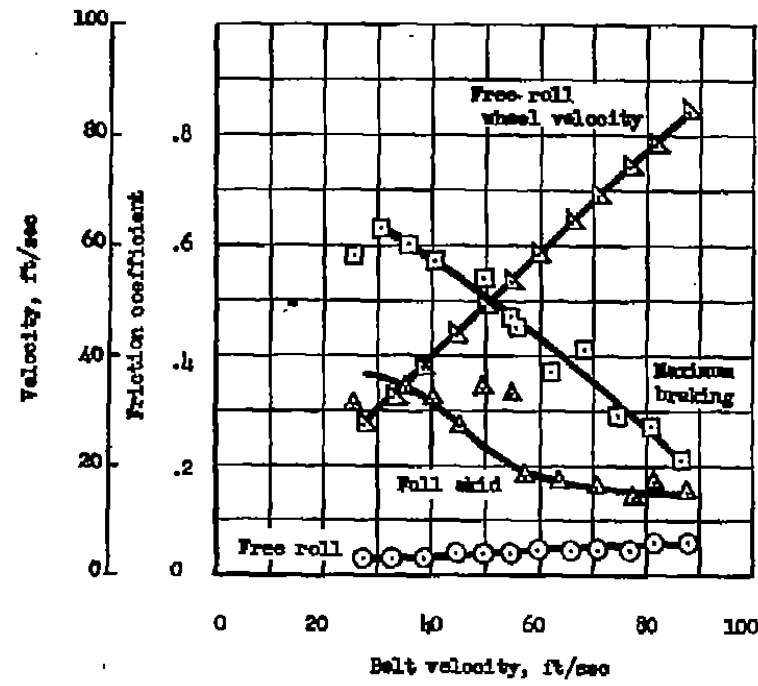

(a) Tire Inflation pressure, $7 \frac{1}{4} \mathrm{lb} / \mathrm{sq}$ in. gage.

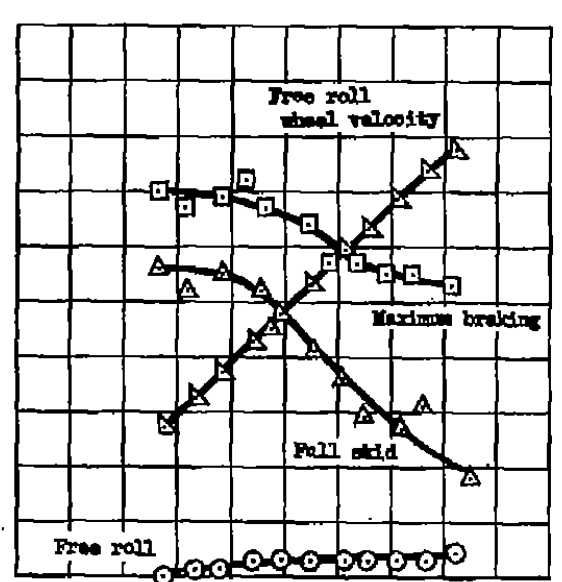

20

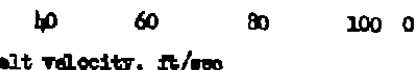

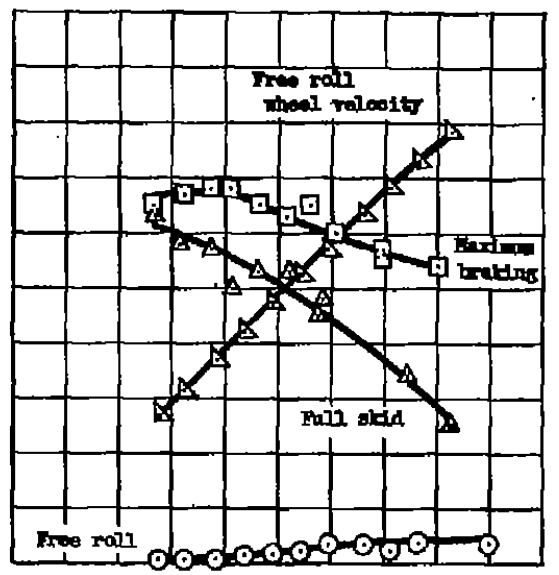

(b) Tire inflation pressure, $16 \mathrm{lb} / \mathrm{sq}$ in. gage.

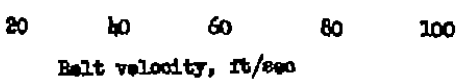

(c) Tire Inflation pressure, $30 \mathrm{lb} / \mathrm{sq}$ 1n. gage.

Figure 10.- Variation of tire friction coefficient and wheel velocity with belt velocity.

$0.02-1$ inch water depth; dlamond-treaded tire; $0^{\circ}$ yaw angle; vertical static loed, 100 pounds. 

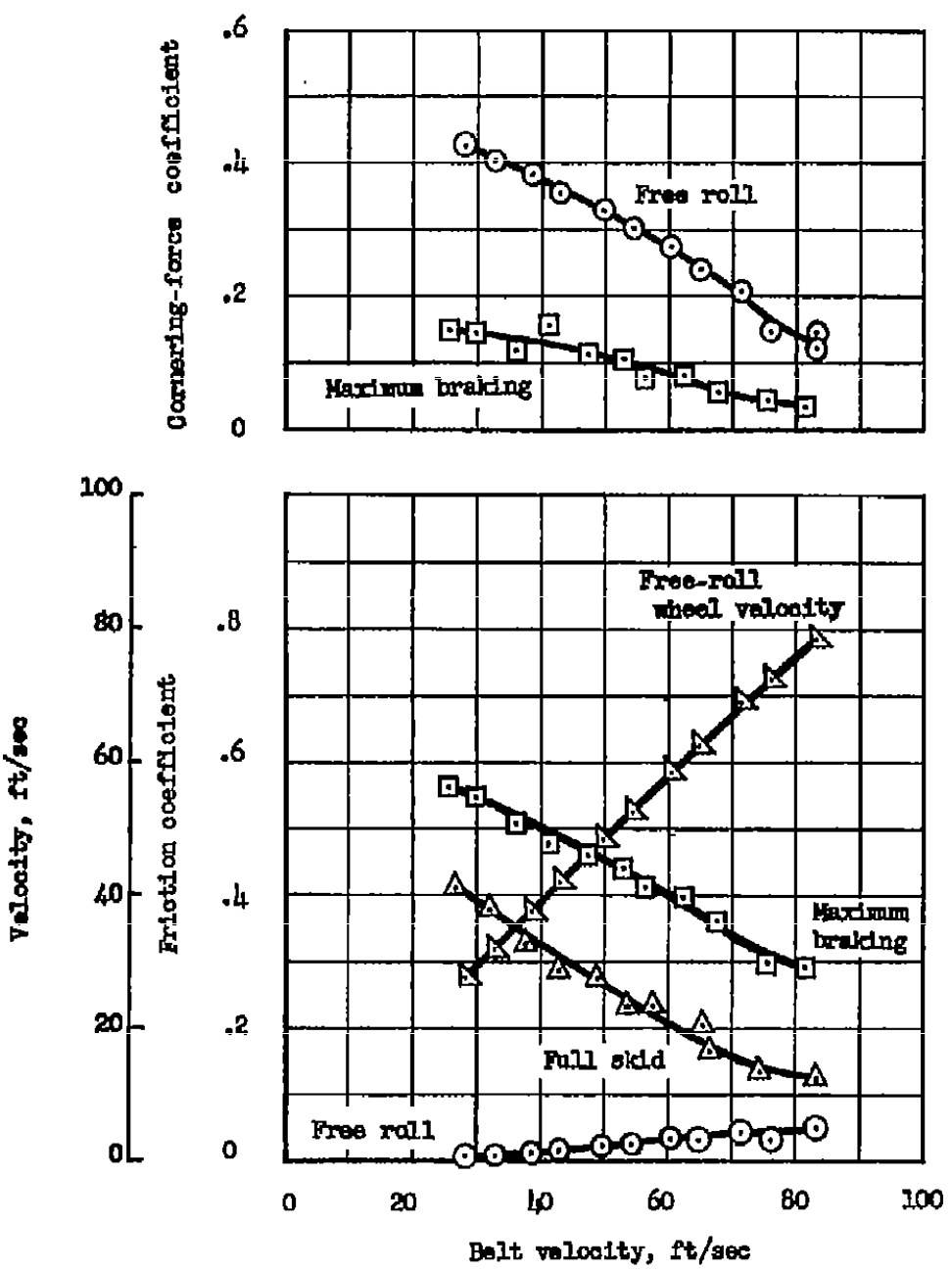

Figure 11.- Varlation of tire frlction coefficient, cornering-force coefficlent, and wheel. velocity with belt velocity. 0.02-1nch water depth; diamond-treaded tire; 40 yaw angle; vertical static load, 100 pounds; tire inflation pressure, $13 \frac{1}{2} \mathrm{lb} / \mathrm{sq}$ in. gage. 


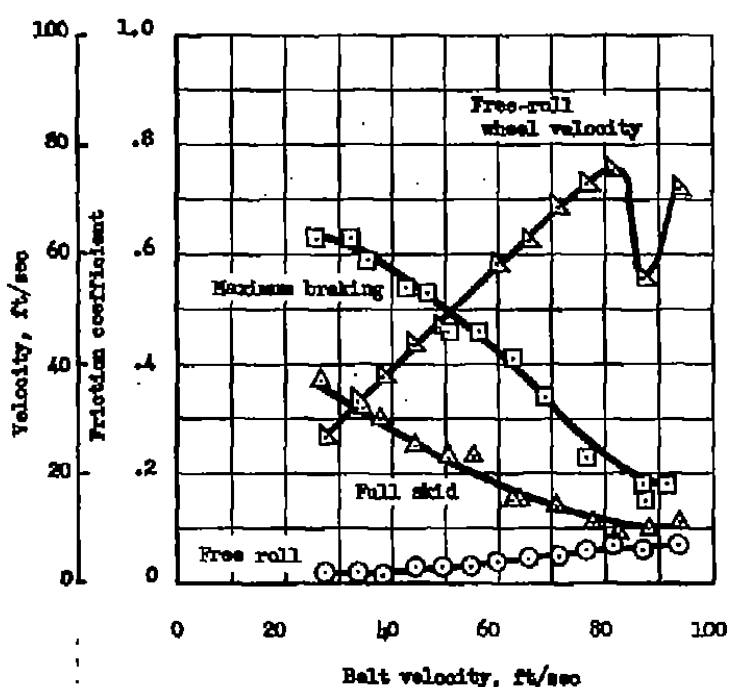

(a) Tire inflation pressure, $6 \mathrm{lb} / \mathrm{sq}$ in. gage.

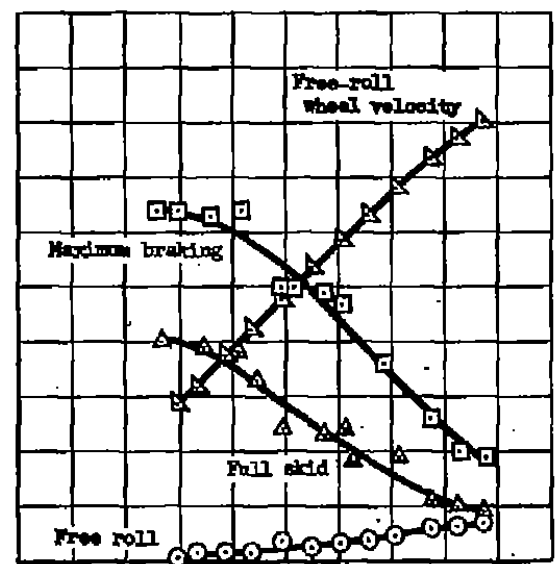

20

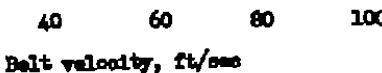

Bart veloodty, $2 t / 60$

(b) Tire inflation pressure, $13 \frac{1}{2} \mathrm{lb} / \mathrm{sq}$ in. gage.

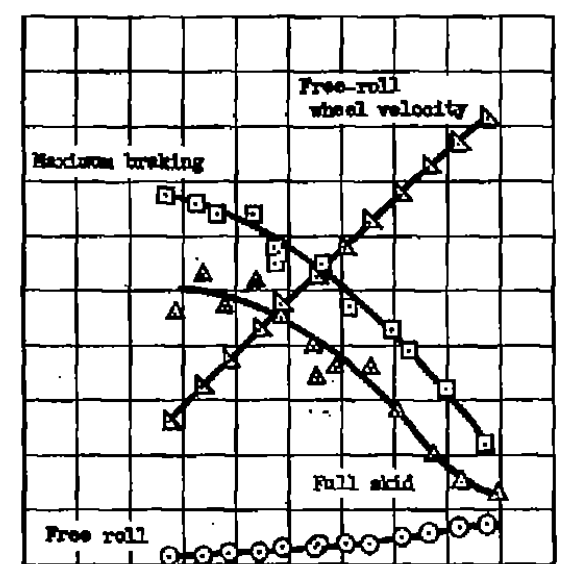

o

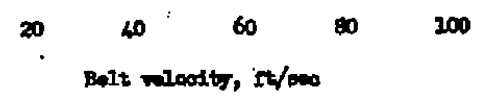

(c) Tire inflation pressure, $28 \frac{1}{2} \mathrm{lb} / \mathrm{sq} \mathrm{In}$. gage.

Figure 12.- Varlation of tire friction coefflcient and wheel velocity with belt veloctty.

0.06-inch water depth; dlamond-treaded tire; $0^{\circ}$ yaw angle; vertical static load, 100 pounds. 


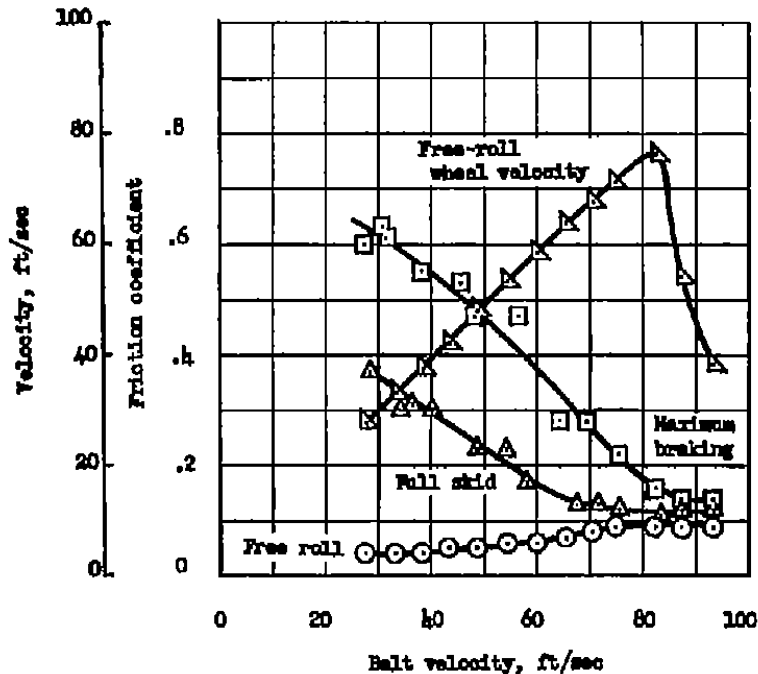

(a) Tire inflation pressure, $6 \mathrm{lb} / \mathrm{sq} \mathrm{in}$. gage.

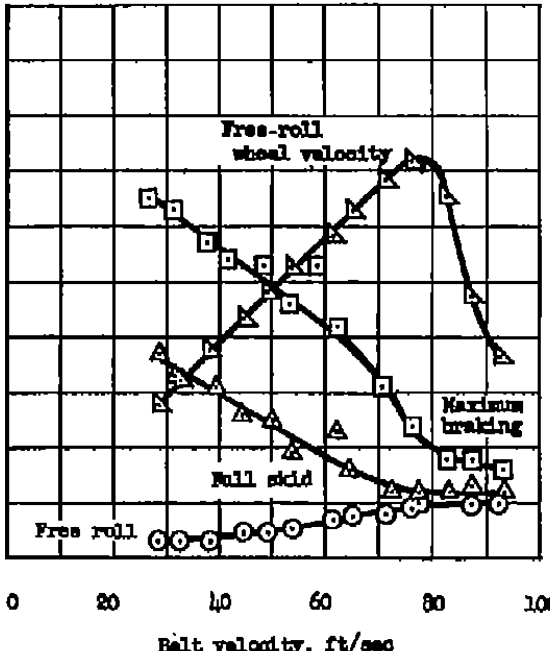

(b) Tire inflation pressure, $13 \frac{1}{2} 1 b / \mathrm{sq}$ in. gage.

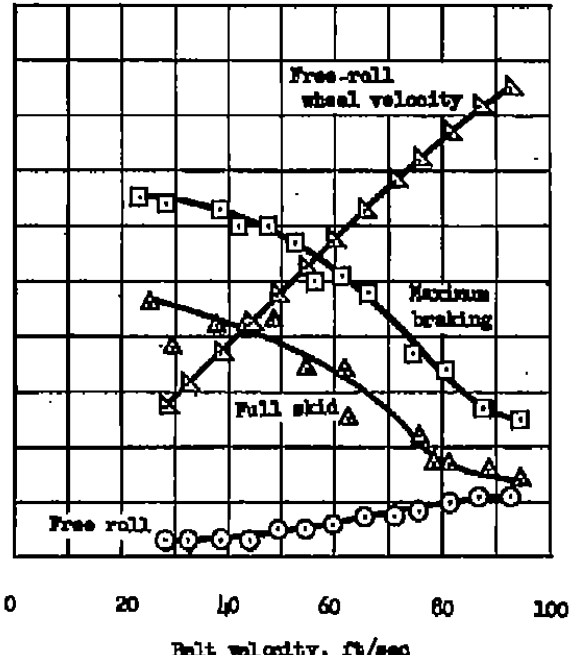

(c) Tire Inflation pressure, $28 \frac{3}{4} \mathrm{lb} / \mathrm{sq}$ in. gage.

Figure 13.- Variation of tire friction coefficient and wheel velocity with belt velocity. 0.09-Inch rater depth; diamond-treaded tire; $0^{\circ}$ yaw angle; vertical stat1c $10 a d, 100$ pounds. 

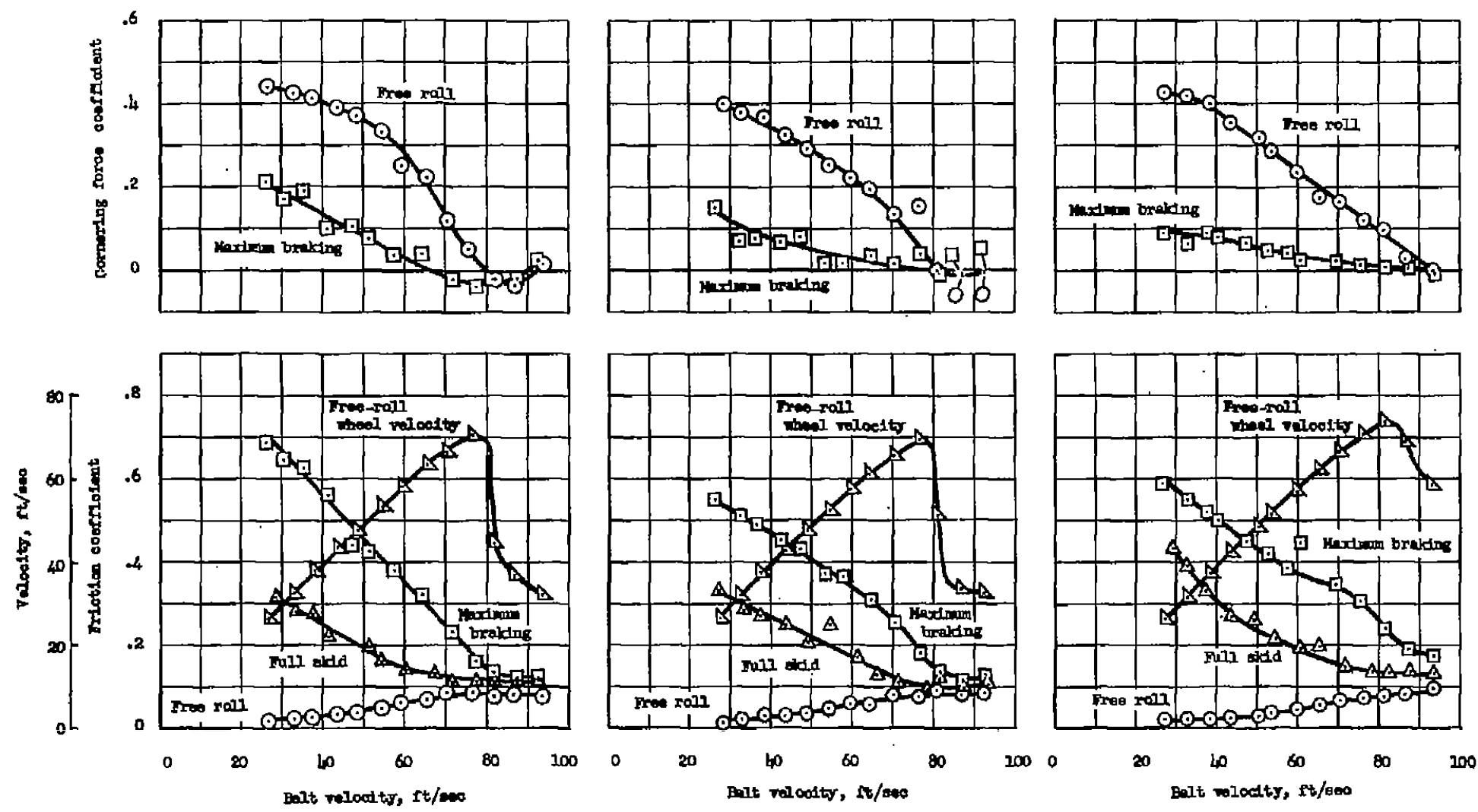

(a) Tire inflation pressure, $7 \mathrm{lb} / \mathrm{sq}$ in. gage.

(b) Tire inflation pressure, $13 \frac{1}{2} 1 \mathrm{~b} / \mathrm{sq}$ in. gage. (c) Tire inflation pressure, $28 \mathrm{lb} / \mathrm{sq} \mathrm{in}$. gage.

Figure 14.- Variation of tire friction coefficlent, cornering-force coefficient, and wheel velocity whth belt velocity. 0.09 -inch water depth; diamond-treaded tire; $4^{b}$ yaw angle; vertical static loed, 100 pounds. 


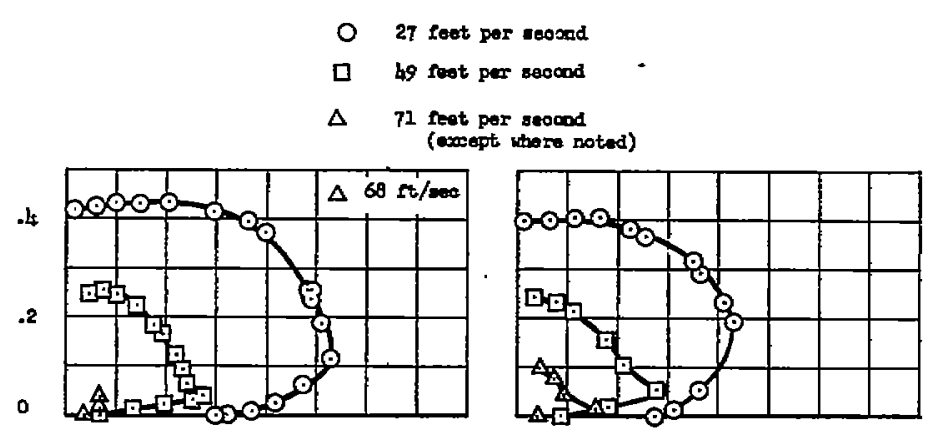

(a) Tire inflation pressure, (d) Tire inflation pressure, $7 \frac{1}{2} \mathrm{lb} / \mathrm{sq}$ in. gage;

0.09-inch water depth: $7 \frac{1}{2} 1 \mathrm{~b} / \mathrm{sq}$ in. gage;

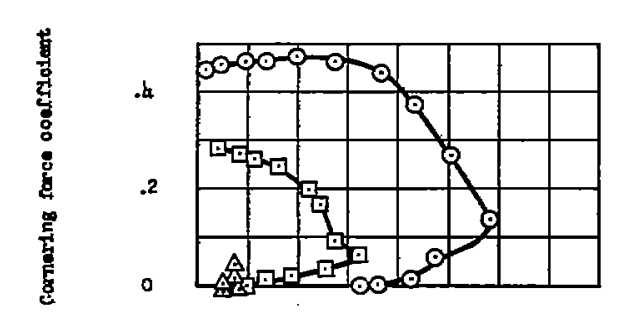
0.02 -inch water depth.

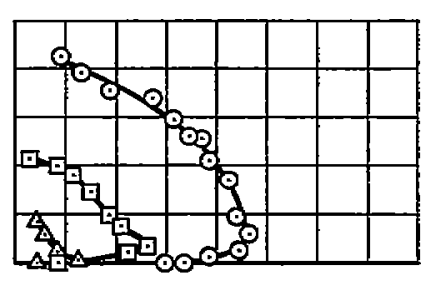

(b) Tire inflation pressure, (e) Tire inflation pressure, $13 \frac{1}{2} \mathrm{lb} / \mathrm{sq}$ in. gage; $13 \mathrm{Ib} / \mathrm{sq}$ in. gage;

0.09-inch water depth. $0.02-i n c h$ water depth.
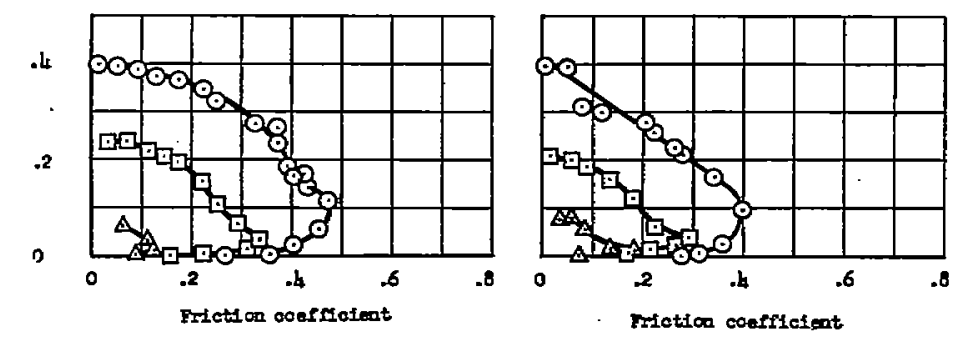

(c) Tire inflation pressure, (f) Tire inflation pressure, $\begin{array}{ll}28 \mathrm{lb} / \mathrm{sq} \text { in. gage; } & 27 \frac{1}{2} \mathrm{lb} / \mathrm{sq} \text { in. gage; } \\ 0.09 \text {-inch water depth. } & 0.02 \text {-inch water depth. }\end{array}$

Figure 15.- Variation of the cornering force coefficient with braking friction coefficient at three belt velocities. Smooth tire; $0.02-1$ inch and 0.09 -inch water depths on the belt; $4^{\circ}$ yaw angle; and vertical static load, 100 pounds. 


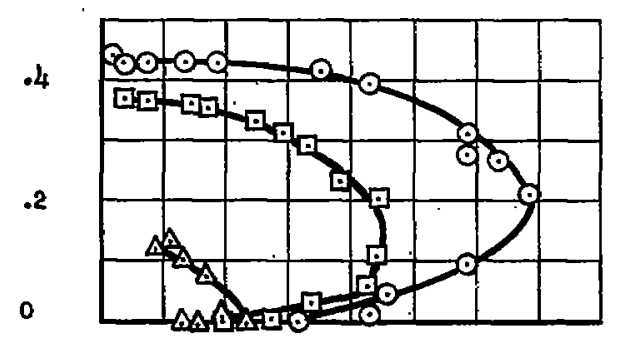
O 27 feet per second
口 49 feet per second
$\Delta \quad 7$ feet per socond

(a) Tire inflation pressure, $7 \mathrm{Ib} / \mathrm{sq}$ in. gage;

0.09-Inch water depth.

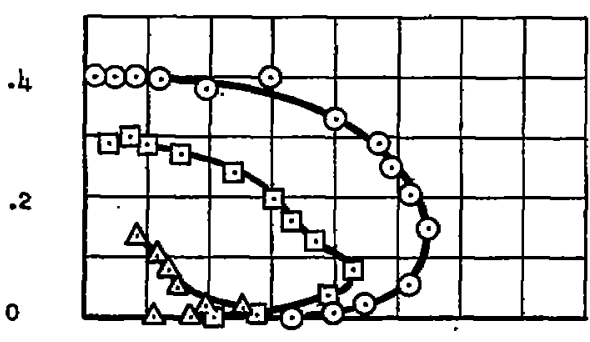

(b) Tire inflation pressure, $13 \frac{l}{2} 1 \mathrm{~b} / \mathrm{sq}$ in. gage;

0.09-inch water depth.

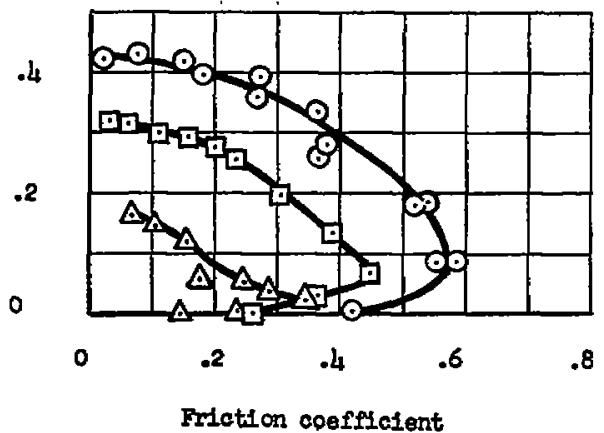

(c) Tire inflition pressure, $28 \mathrm{lb} / \mathrm{sq}$ in. gage;

0.09-inch water depth.

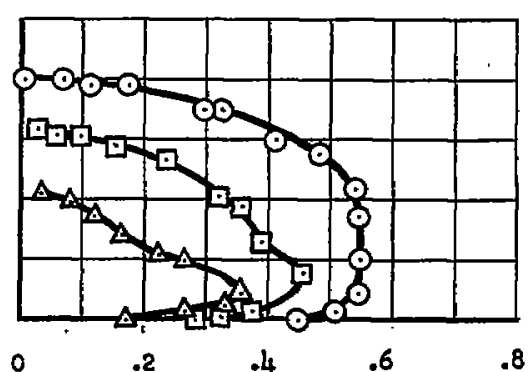

Friction coeffloient

(d) Tire inflation pressure, $13 \frac{1}{2} \mathrm{lb} / \mathrm{sq}$ in. gage;

0.02-Inch water depth.

Figure 16.- Variation of the cornering-force coefficlent with braking friction coefficient at three belt velocities. Diamond-treaded tire; 0.02 -inch and 0.09-1nch water depths on the belt; $4^{\circ}$ yaw angle; vertical static load, 100 pounds. 


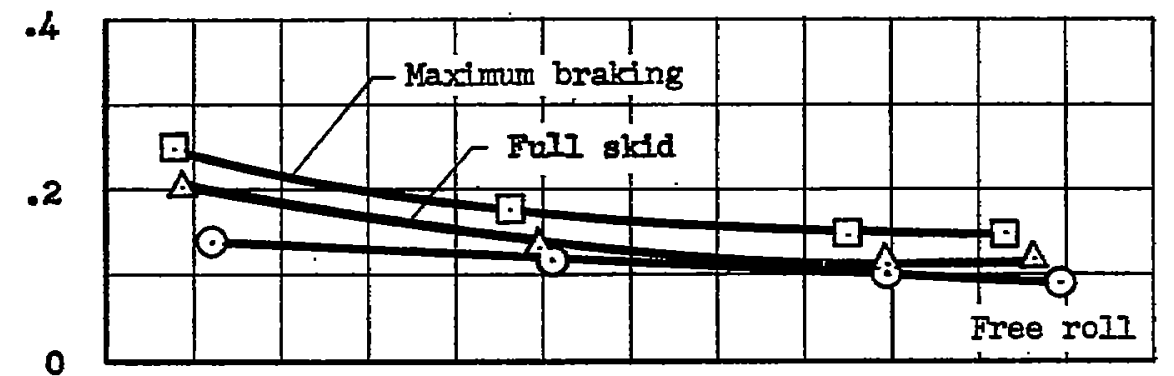

(a) Tire inflation pressure, $7 \mathrm{lb} / \mathrm{sq}$ in. gage.

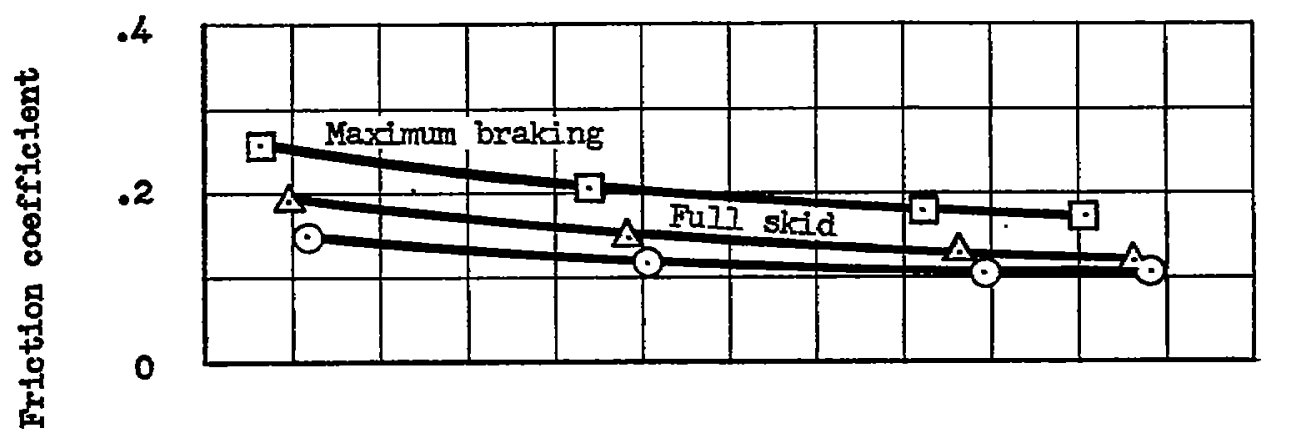

(b) Tire inflation pressure, $14 \mathrm{lb} / \mathrm{sq}$ in. gage.

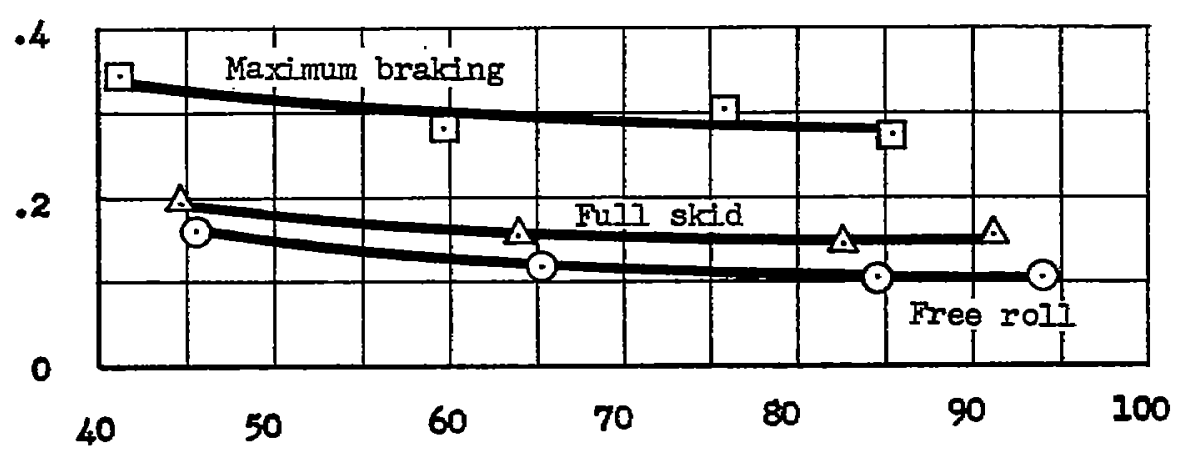

Verticel ground resction, Ib

(c) Tire inflation pressure, $28 \frac{1}{2} \mathrm{lb} / \mathrm{sq}$ in. gage.

Figure 17.- Effect of the vertical ground reaction on the friction coefficient at maximum braking, free roll, and full skid for the diamond-treaded all-weather tire. 0.09-inch water depth; $82 \mathrm{ft} / \mathrm{sec}$ belt velocity. 